\title{
Gender Discrimination Perception among Maritime Students in Turkey
}

\author{
Volkan FİDAN, Esin GÜNAY, Gamze AKPINAR, Can ATACAN
}

\author{
Ege University, Urla Maritime Vocational School, Turkey \\ volkan.fidan@ege.edu.tr; ORCID ID: https://orcid.org/0000-0002-7558-4667 \\ esin.gunay@ege.edu.tr; ORCID ID: https://orcid.org/0000-0002-3851-0108 \\ gamze.akpinar@ege.edu.tr; ORCID ID: https://orcid.org/0000-0002-6876-8601 \\ can.atacan@ege.edu.tr; ORCID ID: https://orcid.org/0000-0002-4490-7566 \\ Corresponding Author: Volkan FIDAN
}

\begin{abstract}
Gender discrimination is a controversial issue that is being debated around the world, independently the level of development of countries. This discrimination is tried to be prevented by legal regulations. However, it is a practice problem rather than law in business life.

The maritime sector is one of the sectors considered to be more prevalent in stereotypes of gender roles. It is thought that this discrimination is applied more in occupational groups that require physical force. It was aimed to determine the perceptions of associate degree students in maritime programmes about gender discrimination related to maritime profession at public universities across Turkey.

The result of the study reveals that the perception of gender discrimination is higher among female students than male. Especially Underwater Technology students' perception of gender discrimination is higher than Maritime Transport and Management, and Yacht Master students. It proves that women can not find any job in the industrial diving sector due to restrictions of Turkish Labor Law although they have education in Underwater Technology programmes.
\end{abstract}

\section{Keywords}

Gender Discrimination, Maritime Profession, Perception of Maritime Students.

\section{Introduction}

Literally, "equality" is the right of different groups of people to be subjected to similar social positions and practices. Gender discrimination is defined as a situation where people who are equal in quality are treated differently depending on their gender only [1].

The roles and responsibilities expected from individuals born and equipped with different genetic, physiological, and biological features, are expressed as the concept of gender. Although judgments about the importance attributed to gender discrimination vary in different societies at different times, it is seen that there are different attitudes according to the gender of the individuals in terms of using

To cite this article: Fidan,V., Günay, E., Akpınar, G. \& Atacan C. (2020). Gender Discrimination Perception among Maritime Students in Turkey. Journal of ETA Maritime Science, 8(3), 162-176.

To link to this article: https://dx.doi.org/10.5505/jems.2020.31932 
opportunities, benefiting resources, and accessing services [2]. This concept, which we encounter in many areas of society, is also one of the most important issues of the labor markets. An important part of the labor force, which forms the basis of development and economic growth, is exposed to the issue of discrimination based on gender and this causes the economy to lose its ability to adapt to change [3].

Throughout history, women, like men, have been involved in working life in order to contribute to the family and national economy. Despite the difficulties and gender discrimination they faced in business life, they tried to acquire their own position and title in every field of life.

It is undeniable fact that deep legal changes are needed to guarantee women's rights in the world. Discrimination against women in social and legal norms continues in many countries. As of 2014, 143 of 195 countries have recognized equality between women and men, but 52 other countries have not take any steps in this regard. There has been gender discrimination in the economic and political sectors over the past decade, and women earn $24 \%$ less than men in the global job market [4]. The gender barrier denies the potential of many women in terms of opportunities and empowerment, both in current and business life. Gender equality and women's empowerment can be described as the basic dimensions of human development. Development and improvement activities involving half of humanity and without women are not universal [5]. World Economic Forum founder Klaus SCHWAB emphasized that societies, where women are ignored, will lose their talents, ideas, and perspectives for new opportunities against global challenges. He says that there is a relative gap between women and men are in the fields of health, education, economy, and politics and he emphasizes that the integration of women into the talent pool in the innovative capacity of countries should be made imperative [6].

Gender discrimination remains one of the biggest obstacles to social development. Another dangerous aspect of discrimination is that negativity in the quality of social cohesion can also slow human development [7].

According to the Global Gender Gap Report 2020 of World Economic Forum Iceland is the top performer country in gender discrimination and Turkey is ranked at the 130 of 149 [8]. The report provides data that it would take 108 years for women to have equal rights with men and 202 years for men to have equal pay. Turkey as a member of OECD, draws a chart that falls far behind the OECD countries also. Women's labor force participation rate was 32.8\% in the OECD's report for the last quarter of 2018, while that of men was $69.9 \%$ [9]. This ratio reveals its place in the working life of women in Turkey.

TurkStat 2017 data, which includes labor force participation rates based on educational status in Turkey, shows that women are more likely to join the labor force as education levels rise. The labour force participation rates are as follows: illiterate women \%15.9 high educated women $\% 27.7$ high school graduate women \%34.3, vocational or technical high school graduate women \%42.9, higher education \%72.7. According to the results of the household labour force survey; in 2017, the proportion of men employed in Turkey aged 15 and above was $65.6 \%$, while the proportion of women was $28.9 \%$ [10].

In today's working life, there are stereotyped prejudgements about gender in some occupational groups. The maritime sector is also a genderdiscriminated occupational group. The place of female seafarers among 1.25 million sailors worldwide does not exceed 1-2 \%. In addition, women's participation in the maritime transportation sector is $17-18 \%$ [11]. 
According to data from the T.R. Ministry of Transport and Infrastructure May 2017, the proportion of female officers in the sector is $2 \%$. This data is shown below in Table 1 [12].

Table 1. Licenced Turkish Women Officers on Maritime Sector

\begin{tabular}{|l|c|c|}
\hline Rank & $\begin{array}{c}\text { Women } \\
\text { Officers }\end{array}$ & $\begin{array}{c}\text { Total Officers } \\
\text { (Women + } \\
\text { Men) }\end{array}$ \\
\hline $\begin{array}{l}\text { Oceangoing } \\
\text { Watchkeeping } \\
\text { Officer }\end{array}$ & 141 & 2813 \\
\hline $\begin{array}{l}\text { Oceangoing } \\
\text { Chief Officer }\end{array}$ & 48 & 1886 \\
\hline $\begin{array}{l}\text { Oceangoing } \\
\text { Master }\end{array}$ & 31 & 3423 \\
\hline $\begin{array}{l}\text { Oceangoing } \\
\text { Watchkeeping } \\
\text { Engineer }\end{array}$ & 26 & 1530 \\
\hline $\begin{array}{l}\text { Oceangoing } \\
\text { First Engineer }\end{array}$ & 1 & 937 \\
\hline $\begin{array}{l}\text { Oceangoing } \\
\text { Chief Engineer }\end{array}$ & 7 & 1886 \\
\hline $\begin{array}{l}\text { Total } \\
\text { Source: }\end{array}$ & 254 & \\
\hline
\end{tabular}

Source: [12].

In addition, according to the Food and Agriculture Organization (FAO) data, the employment participation rate of women in fisheries and aquaculture areas is only $14 \%$ in 2014. Despite the new arrangements intended to improve the existing situation, women are still excluded from mainstream maritime activities and many countries still pursue gender-blind maritime policies [13].

As in the world, women are a minority in the maritime sector in Turkey. This makes it necessary for women to make more effort to get themselves involved in the industry. Efforts to establish women's identity in the sector are not much supported by family members and employers. The entry of women into the men-dominated maritime sector is seen as an invasion by men [14]. However, women's performance in the maritime sector should not be measured by their gender.

Prejudice and attitudes towards gender discrimination are not limited only to the reaction of family and employers. Articles stated in labor law like "It is forbidden to employ men under eighteen years of age and women of all ages in underground or underwater works such as mine and cable laying, sewerage and tunnel construction" completely abolishes the employment of women divers. Women divers who are allowed to receive training in the underwater sector are prevented from working in the sector by this regulation.

International Maritime Organization (IMO) nominated the year of 2019 as "The Year of Maritime Women \& Increasing Awareness of Maritime Women". International Labor Organization (ILO) and the International Transport Workers' Federation (ITF) put regulating rules against gender discrimination as the International Maritime Organization. These non-governmental organizations strive to break the taboo that maritime is a male-dominated sector. Despite these positive efforts, women seafarers consist of 1.2 million seafarers population [15].

It can be stated that gendered approaches have been adopted in the maritime sector in the world and in Turkey. This study is based on the idea that there are stereotypes of gendered attitudes in industrial divers, ship officers, and yacht master professions. In this context, it is aimed to identify the perceptions of gender discrimination in the maritime profession of associate degree students who are studying in the fields of Underwater Technology, Maritime Transportation and Management, and Yacht Master Programs in Turkey. Some studies on gender discrimination and their results are shown below in Table 2. 
Table 2. Previous Studies on Gender Discrimination

\begin{tabular}{|c|c|c|c|}
\hline Authors & Researches & Aim of Researches & Outcomes \\
\hline $\begin{array}{l}\text { Sanchez ve } \\
\text { Brock (1996) } \\
{[16]}\end{array}$ & $\begin{array}{l}\text { Outcomes Of Perceived } \\
\text { Discrimination Among } \\
\text { Hispanic Employees: Is } \\
\text { Diversity Management A } \\
\text { Luxury Or A Necessity? }\end{array}$ & $\begin{array}{l}\text { Investigating the effect } \\
\text { of discrimination } \\
\text { perception on employee } \\
\text { production }\end{array}$ & $\begin{array}{l}\text { The perception of discrimination } \\
\text { affects employees above and } \\
\text { beyond other factors causing work } \\
\text { stress and affects the production of } \\
\text { employees. }\end{array}$ \\
\hline $\begin{array}{l}\text { Gutek et al. } \\
\text { (1996) [17] }\end{array}$ & $\begin{array}{l}\text { Reactions to perceived } \\
\text { sex discrimination }\end{array}$ & $\begin{array}{l}\text { To investigate the } \\
\text { relevance of perceived } \\
\text { discrimination } \\
\text { in business and } \\
\text { organizational life to } \\
\text { individuality }\end{array}$ & $\begin{array}{l}\text { While workers perceived relatively } \\
\text { less discrimination, women } \\
\text { perceived more discrimination } \\
\text { against them than men, and when } \\
\text { the two sexes were dealt with at the } \\
\text { same time, it was determined that } \\
\text { women were discriminated against } \\
\text { more than men }\end{array}$ \\
\hline $\begin{array}{l}\text { Brickman } \\
\text { (2008) [18] }\end{array}$ & $\begin{array}{l}\text { Maritime Education } \\
\text { And Training of Women: } \\
\text { Their Impact On The } \\
\text { Program At The United } \\
\text { States Merchant Marine } \\
\text { Academy }\end{array}$ & $\begin{array}{l}\text { To investigate changes in } \\
\text { maritime education and } \\
\text { training following the } \\
\text { inclusion of women as } \\
\text { students in the Maritime } \\
\text { Academy }\end{array}$ & $\begin{array}{l}\text { Changes in maritime education } \\
\text { and training have been achieved } \\
\text { following the inclusion of women as } \\
\text { students in the Maritime Academy. }\end{array}$ \\
\hline $\begin{array}{l}\text { Onay (2009) } \\
\text { [19] }\end{array}$ & $\begin{array}{l}\text { The Consequences } \\
\text { Of Perceived Gender } \\
\text { Discrimination And } \\
\text { An Empirical Research } \\
\text { Related With The Topic }\end{array}$ & $\begin{array}{l}\text { To be able to identify the } \\
\text { relationship between } \\
\text { variables that help to } \\
\text { identify the concept of } \\
\text { sex discrimination in } \\
\text { individuals }\end{array}$ & $\begin{array}{l}\text { Female employees perceive } \\
\text { discrimination more than men. In } \\
\text { addition, gender discrimination } \\
\text { among employees affects their } \\
\text { organizational commitment and } \\
\text { increases employees' intention to } \\
\text { quit. }\end{array}$ \\
\hline Arlı (2013) [20] & $\begin{array}{l}\text { Gender Segregation and } \\
\text { Gender Bias Perceived } \\
\text { in Marine Tourism: A } \\
\text { Research on the Students } \\
\text { of Karamürsel Vocational } \\
\text { Higher School }\end{array}$ & $\begin{array}{l}\text { To identify what is the } \\
\text { perception of gender } \\
\text { discrimination and gender } \\
\text { bias among university } \\
\text { students in maritime tourism } \\
\text { education }\end{array}$ & $\begin{array}{l}\text { It was determined that there was } \\
\text { a statistically significant difference } \\
\text { between female and male students' } \\
\text { perceptions of occupational sex } \\
\text { discrimination and prejudice against } \\
\text { women. It was also determined that } \\
\text { female students were aware of the } \\
\text { gender discrimination applied to women } \\
\text { in this area }\end{array}$ \\
\hline Nas (2014) [21] & $\begin{array}{l}\text { A Study On Short Historical } \\
\text { Process Of Professional } \\
\text { Turkish Women Seafarers }\end{array}$ & $\begin{array}{l}\text { To explain the process } \\
\text { from the admission of } \\
\text { Turkish women to maritime } \\
\text { education institutions to the } \\
\text { professional careers they } \\
\text { reach today. }\end{array}$ & $\begin{array}{l}\text { The proportion of female seamen } \\
\text { candidates in maritime training } \\
\text { institutions was found to be } 5 \% \text { of the } \\
\text { total student quota of these institutions. } \\
\text { While this proportion in educational } \\
\text { institutions has been maintained, very } \\
\text { few of the female sailors working on } \\
\text { ships have achieved the high-level } \\
\text { qualifications of the maritime profession. }\end{array}$ \\
\hline $\begin{array}{l}\text { Cömert (2014) } \\
\text { [22] }\end{array}$ & $\begin{array}{l}\text { Thoughts about Their } \\
\text { Sectoral Working Areas } \\
\text { and Sex Discrimination in } \\
\text { Employment by Students } \\
\text { Who Are Taking Tourism } \\
\text { Training }\end{array}$ & $\begin{array}{l}\text { To determine the thoughts } \\
\text { about their sectoral working } \\
\text { areas, whether gender factor } \\
\text { affects these preferences, } \\
\text { and students ' thoughts on } \\
\text { gender factor in recruitment } \\
\text { and promotion processes } \\
\text { from tourism sector. }\end{array}$ & $\begin{array}{l}\text { The department where male employees } \\
\text { want to work the most is the service } \\
\text { ( } 32.5 \%) \text { and the department where } \\
\text { female employees want to work the most } \\
\text { is the housekeeping service }(15.9 \%) \text {. } \\
\text { The perception that some jobs are } \\
\text { considered women's work and some jobs } \\
\text { are considered men's work is supported. }\end{array}$ \\
\hline
\end{tabular}


Table 2. Previous Studies on Gender Discrimination (Cont')

\begin{tabular}{|c|c|c|c|}
\hline Authors & Researches & Aim of Researches & Outcomes \\
\hline $\begin{array}{l}\text { Davras \& } \\
\text { Davras (2015) } \\
{[23]}\end{array}$ & $\begin{array}{l}\text { Thoughts about sex } \\
\text { discrimination in tourism } \\
\text { sector by students who } \\
\text { are in Gastronomy and } \\
\text { Culinary Program }\end{array}$ & $\begin{array}{l}\text { The aim of this study } \\
\text { was to identify the } \\
\text { students' thoughts on } \\
\text { gender discrimination } \\
\text { in the recruitment and } \\
\text { promotion processes in } \\
\text { the kitchen. }\end{array}$ & $\begin{array}{l}\text { Students stated that the most } \\
\text { gender discrimination was in } \\
\text { promotion and recruitment, while } \\
\text { the least was in the salary. Female } \\
\text { students' perceptions of gender } \\
\text { discrimination were higher than } \\
\text { male students' }\end{array}$ \\
\hline $\begin{array}{l}\text { Nemlioğluı } \\
\text { Koca (2015) } \\
{[24]}\end{array}$ & $\begin{array}{l}\text { The Perception of Gender } \\
\text { Discrimination And } \\
\text { Prejudice in Maritime: A } \\
\text { Research on the Students } \\
\text { of Barbaros Maritime } \\
\text { School }\end{array}$ & $\begin{array}{l}\text { Gender discrimination in } \\
\text { maritime education and } \\
\text { students' perceptions } \\
\text { of bias were tried to be } \\
\text { determined. }\end{array}$ & $\begin{array}{l}\text { A statistically significant } \\
\text { relationship between gender } \\
\text { and gender discrimination and } \\
\text { prejudice has been revealed. } \\
\text { Accordingly, the result is that } \\
\text { the gender of the students } \\
\text { influences their thoughts on } \\
\text { gender discrimination and } \\
\text { prejudice. It is revealed that } \\
\text { there is a directly proportional } \\
\text { relationship between gender } \\
\text { discrimination and prejudice, and } \\
\text { that gender discrimination can } \\
\text { also be eliminated by eliminating } \\
\text { prejudices }\end{array}$ \\
\hline $\begin{array}{l}\text { Özcan et al. } \\
\text { (2017) [25] }\end{array}$ & $\begin{array}{l}\text { A Research About } \\
\text { Prediction on Gender } \\
\text { Discrimination Related to } \\
\text { Engineering }\end{array}$ & $\begin{array}{l}\text { Gender perceptions and } \\
\text { prejudices for senior } \\
\text { students in industrial } \\
\text { engineering and } \\
\text { engineering profession } \\
\text { are examined. }\end{array}$ & $\begin{array}{l}\text { Students found Industrial } \\
\text { Engineering appropriate in terms } \\
\text { of their gender. While students' } \\
\text { perception of men's profession as } \\
\text { an engineering profession differed } \\
\text { significantly by gender, it did not } \\
\text { differ by other demographics. } \\
\text { Prejudices regarding gender } \\
\text { discrimination in the engineering } \\
\text { profession differ only by their } \\
\text { gender. }\end{array}$ \\
\hline
\end{tabular}

Source: Created by author

\section{Method}

\subsection{The Goal of the Present Research}

The aim of the study is to determine the perceptions of gender discrimination in the maritime profession of associate degree students who are studying in the maritime field (underwater technology, maritime transportation and management, and yacht master) which have not yet been introduced into their working lives. In addition, the findings on gender discrimination according to the profile variables of the students and the existence and reasons of occupational sex discrimination in the maritime profession were tried to be determined.

\subsection{Hypothesis}

(1) Students' perceptions of gender discrimination differ in terms of profile for bulleted lists.

- "gender".

- "education programme".

- "class level".

- "region where their family lived".

- "family education level".

- "family income level".

- "whether there is a relative in the sector". 


\subsection{Population and Sample of the Research}

The population and sample of research are indicated below in Table 3. In determining the population of the research, it was calculated by taking twice the 2018 quota of the institutions providing underwater technology, marine transportation and management, and yacht master associate degree education in Turkey. However, the number of active students in schools are below the specified set of population (quotas).

\subsection{Instruments}

The first part of the questionnaire involves students' demographic characteristics: gender, education programme, class level, region where their family lived, family education level, family income level, and whether there is a relative in the sector. 10 items of gender discrimination perception have been used with the permission of Prof. Sanchez on 18 April 2018 and developed by Sanchez

Table 3. Population and Sample of The Research

\begin{tabular}{|l|c|c|}
\hline $\begin{array}{l}\text { STATE UNIVERSITIES IN TURKEY PROVIDING EDUCATION IN THE FIELD OF } \\
\text { UNDERWATER TECHNOLOGY PROGRAM }\end{array}$ & POPULATION & SAMPLE \\
\hline EGE UNIVERSITY- (IZMIR) Urla Maritime Vocational School & 100 & 51 \\
\hline ISTANBUL UNIVERSITY -CERRAHPAŞA Vocational School of Technical Sciences & 60 & 19 \\
\hline İSKENDERUN TECHNICAL UNIVERSITY- (HATAY) Maritime Vocational School & 60 & 16 \\
\hline ÇUKUROVA UNIVERSITY- (ADANA) Yumurtalık Vocational School & 50 & 5 \\
\hline SINOP UNIVERSITY Vocational School & 60 & 14 \\
\hline $\begin{array}{l}\text { RECEP TAYYIP ERDOĞAN UNIVERSITY- (RIZE) Vocational School of Technical } \\
\text { Sciences }\end{array}$ & 70 & 34 \\
\hline $\begin{array}{l}\text { STATE UNIVERSITIES IN TURKEY PROVIDING EDUCATION IN THE FIELD OF } \\
\text { MARITIME TRANSPORTATION AND MANAGEMENT PROGRAM }\end{array}$ & POPULATION & SAMPLE \\
\hline EGE UNIVERSITY- (IZMIR) Urla Maritime Vocational School & 120 & 92 \\
\hline YALOVA UNIVERSITY- Yalova Vocational School & 120 & 71 \\
\hline MERSIN UNIVERSITY- Maritime Vocational School & 110 & - \\
\hline KOCAELI UNIVERSITY- Karamürsel Vocational School & 160 & 71 \\
\hline YALOVA UNIVERSITY- Yalova Vocational School (Evening Edu.) & 70 & - \\
\hline ORDU UNIVERSITY- Fatsa Vocational School & 120 & 46 \\
\hline GIRESUN UNIVERSITY- Vocational School of Technical Sciences & 40 & 10 \\
\hline MERSIN UNIVERSITY- Maritime Vocational School (Evening Edu.) & 70 & - \\
\hline GALATASARAY UNIVERSITY- (ISTANBUL) Vocational School (Evening Edu.) & 50 & 25 \\
\hline $\begin{array}{l}\text { STATE UNIVERSITIES PROVIDING TRAINING IN THE FIELD OF YACHT } \\
\text { MASTER PROGRAM }\end{array}$ & POPULATION & SAMPLE \\
\hline MUĞLA SITKI KOÇMAN UNIVERSITY- Bodrum Maritime Vocational School & $\mathbf{1 3 2 0}$ & $\mathbf{4 0 2}$ \\
\hline
\end{tabular}

Source: Created by the authors 
and Brock's (1996) and Gutek et al. (1996). In the present study, the questionnaire's overall Cronbach's internal consistency reliability estimate is $0.850(n=402)(r \geq 0.70)$.

\subsection{Analyses}

Data collected by the questionnaire were analysed with SPSS 25.0 program.

- Frequency analyses of the responses of the students to the questions aimed at revealing their demographic characteristics were carried out. Also, skewness and kurtosis values of these variables were used to determine whether the distribution of variables were parametric or not. For kurtosis and skewness values, it is assumed to be a normal distribution when it is -1.5 to +1.5 [26].
- ANOVA test has been used in the parametric variables of the field of education programme, region where their family lived, family education level, and family income level. Mann Whitney U test was used in the nonparametric variables of gender, class level, and whether there was a relative in the sector.

- ' $\mathrm{e}^{2}$ ' (eta-squared) value was used for measuring the effect size of significant differences in ANOVA tests. The effect size was small if $\mathrm{e}^{2}$ value is smaller than 0.01 , medium if $\mathrm{e}^{2}$ value between 0.01-0.059, and large if $\mathrm{e}^{2}$ is bigger than 0.138. In Mann Whitney U test ' $r$ ' value has been used for measuring the effect size. The effect size is small if $r$ value is smaller than 0.1 , medium if $r$ value is between 0.1-0.3, and large if $r$

Table 4. Frequency Analyses

\begin{tabular}{|c|c|c|c|c|c|c|c|c|c|}
\hline \multicolumn{4}{|c|}{ Education programme } & \multicolumn{3}{|c|}{ Gender } & \multicolumn{3}{|l|}{ Class level } \\
\hline & $\mathbf{N}$ & \multicolumn{2}{|l|}{$\%$} & \multicolumn{2}{|c|}{$\%$} & $\%$ & \multicolumn{2}{|c|}{$\%$} & $\%$ \\
\hline MTM & 244 & \multicolumn{2}{|l|}{60} & Male & 340 & 84 & 1.grade & 225 & 56 \\
\hline UT & 139 & \multicolumn{2}{|l|}{35} & Female & 62 & 16 & 2.grade & 177 & 44 \\
\hline YM & 19 & \multicolumn{2}{|l|}{5} & & & & & & \\
\hline Total & 402 & \multicolumn{2}{|c|}{100} & Total & 402 & 100 & Total & 402 & 100 \\
\hline \multicolumn{4}{|c|}{ Region where the family lived } & \multicolumn{3}{|c|}{ Mother education level } & \multicolumn{3}{|c|}{ Father education level } \\
\hline \multirow{2}{*}{\multicolumn{2}{|c|}{ Marmara }} & $\mathbf{N}$ & $\%$ & \multirow{5}{*}{\multicolumn{2}{|c|}{$\begin{array}{lc} & \text { N } \\
\text { Primary } & 153 \\
\text { Secondary } & 111 \\
\text { High school } & 102 \\
\text { Higher } & 36\end{array}$}} & $\%$ & \multirow{8}{*}{$\begin{array}{l}\text { Primary } \\
\text { Secondary } \\
\text { High school } \\
\text { Higher }\end{array}$} & $\mathbf{N}$ & $\%$ \\
\hline & & 120 & 30 & & & 38 & & 109 & 27 \\
\hline \multicolumn{2}{|c|}{ Aegean } & 110 & 27 & & & 28 & & 137 & 34 \\
\hline \multicolumn{2}{|c|}{ Akdeniz } & 74 & 18 & & & 25 & & l 94 & 23 \\
\hline \multirow{2}{*}{\multicolumn{2}{|c|}{$\begin{array}{l}\text { Karadeniz } \\
\text { İc Anadolu }\end{array}$}} & 58 & 14 & & & 9 & & 62 & 16 \\
\hline & & 22 & 5 & & & & & & \\
\hline \multicolumn{2}{|c|}{ Doğu Anadolu } & 10 & 3 & & & & & & \\
\hline \multicolumn{2}{|c|}{$\begin{array}{l}\text { Güneydoğu } \\
\text { Anadolu }\end{array}$} & 8 & 3 & & & & & & \\
\hline \multicolumn{2}{|c|}{ Total } & 402 & 100 & Total & 402 & 100 & Total & 402 & 100 \\
\hline
\end{tabular}

\begin{tabular}{|c|c|c|c|c|c|}
\hline \multicolumn{3}{|c|}{ Family income level } & \multicolumn{3}{|c|}{ Whether there is a relative in the sector } \\
\hline & $\mathbf{N}$ & $\%$ & & $\mathbf{N}$ & $\%$ \\
\hline $1000-3000 \mathrm{TL}$ & 215 & 54 & Yes & 76 & 19 \\
\hline 3000-6000 TL & 154 & 38 & No & 326 & 81 \\
\hline 6000 or above TL & 33 & 8 & & & \\
\hline Total & 402 & 100 & Total & 402 & 100 \\
\hline
\end{tabular}

Source: Created by the authors

(UT: Underwater Technolgy, MTM: Maritime Transportation and Management, YM:Yacht Master) 
value is bigger than 0.5 [27].

- The students' perceptions of gender discrimination have been indicated low from 1.00 to 2.39 , moderate from 2.40 to 3.39 , and high from 3.40 to 5.00 [24].

\section{Findings}

\subsection{Frequency Analysis}

The frequency analyses of the demographic characteristics of the students participating in the study are given in Table 4.

\subsection{Distribution of Profile Variables}

Skewness and kurtosis values were used to determine the analysis methods for variables of gender, education program, grade level, the region of family, education level of parents, the total income of the family, whether or not they were familiar with the sector. The skewness and kurtosis values of the variables are shown below in Figure 1.
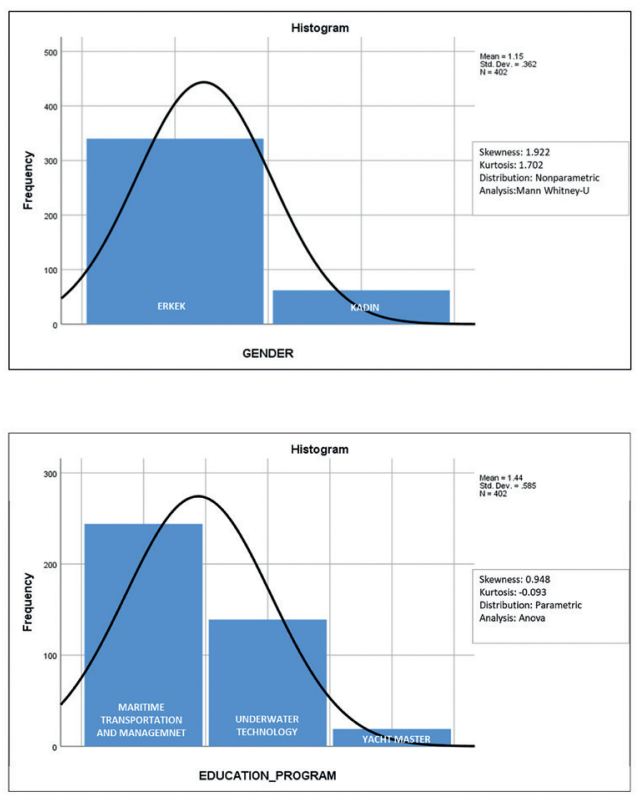
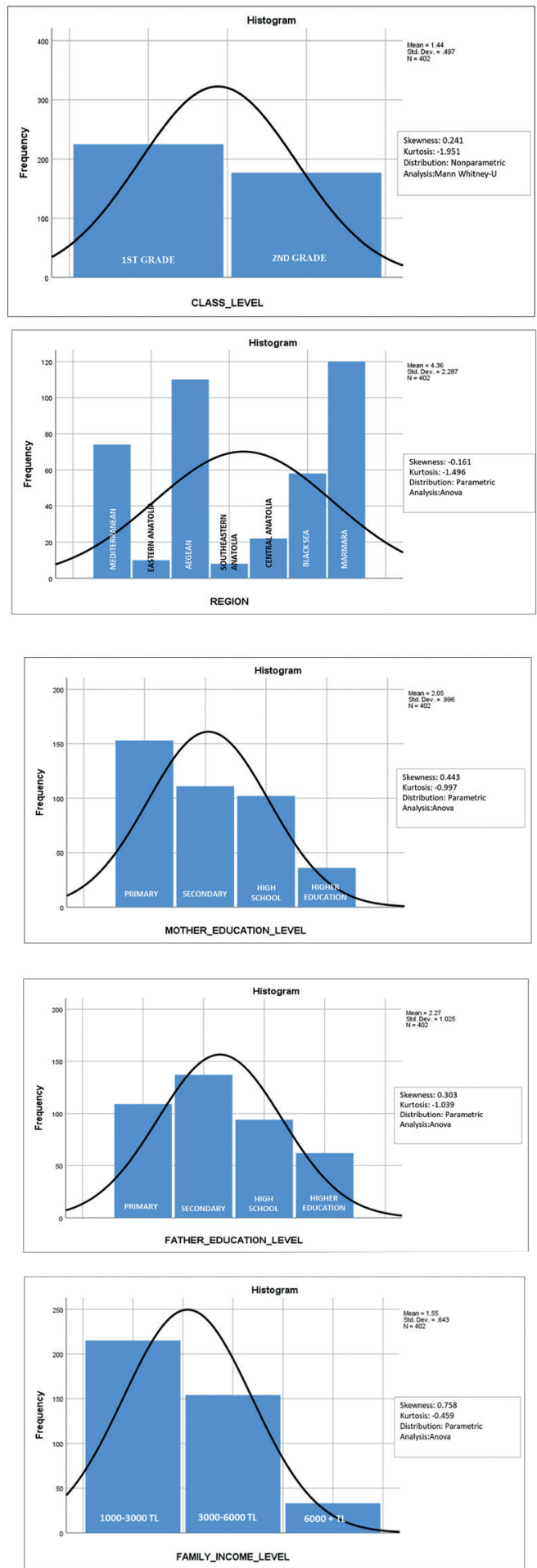

Figure 1. Distributions of Profile Variables and Analysis Methods 


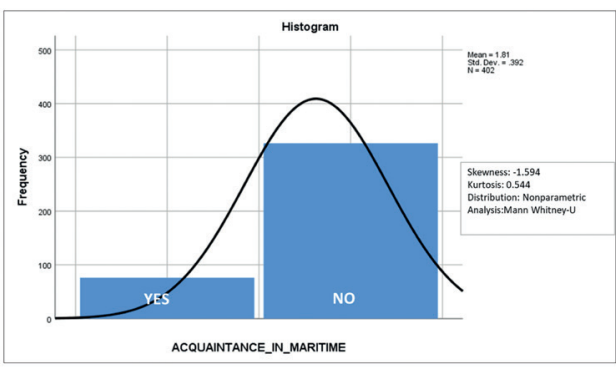

Figure 1. Distributions of Profile Variables and Analysis Methods (Cont')

\subsection{Distributions of Students'} Responses to Statements About Gender Discrimination Perception

Distributions of students' responses to statements about gender discrimination perception are shown below in Table 5. When the response distributions are examined, it is understood that they participate in "I believe women are being treated biased in the maritime industry" (3.6393 \pm 1.180$), \quad$ "I believe there are stereotyped negative thoughts about women working in the maritime industry" (3.6294 \pm 1.162$)$ and "I believe men are more favoured in recruitment in the maritime sector" $(3.7214 \pm 1.099)$ expressions at a high level. It was also revealed that they participated moderately in "I believe that seafaring is perceived as a male profession" (2.6418 \pm 1.402$)$, "I believe there is different remuneration for men and women employees in the maritime sector" (2.5448 \pm 1.143$)$, and "I believe that different legal arrangements have been made for men and women employees in the maritime sector" $(2.6219 \pm 1.170)$ expressions and gave the lowest score.

\subsection{Hypothesis Test Results on Gender Discrimination Based on Students' Profile Information}

Hypothesis tests based on profile information showed significant differences in the variables of gender, education programme, and whether there was an acquaintance in the maritime sector. There were no significant differences in the tests according to the variables of the class level, the region where the family lived, the education level of the parents, and

Table 5. Distributions of Students' Responses to Statements About Gender Discrimination Perception

\begin{tabular}{|c|c|c|c|c|c|c|c|c|c|c|c|c|}
\hline & \multicolumn{2}{|c|}{$\begin{array}{c}\text { Strongly } \\
\text { disagree }\end{array}$} & \multicolumn{2}{|c|}{ Disagree } & \multicolumn{2}{c|}{ Undecided } & \multicolumn{2}{|c|}{ Agree } & \multicolumn{2}{c|}{$\begin{array}{c}\text { Strongly } \\
\text { agree }\end{array}$} & & \\
\hline ST. & $\mathbf{n}$ & $\mathbf{\%}$ & $\mathbf{n}$ & $\mathbf{\%}$ & $\mathbf{n}$ & $\mathbf{\%}$ & $\mathbf{n}$ & $\mathbf{\%}$ & $\mathbf{n}$ & $\mathbf{\%}$ & Mean & SD \\
\hline 1 & 110 & 27.4 & 109 & 27.1 & 51 & 12.7 & 79 & 19.7 & 53 & 13.2 & $\mathbf{2 . 6 4 1 8}$ & 1.402 \\
\hline 2 & 24 & 6.0 & 59 & 14.7 & 57 & 14.2 & 160 & 39.8 & 102 & 25.4 & $\mathbf{3 . 6 3 9 3}$ & 1.180 \\
\hline 3 & 26 & 6.5 & 53 & 13.2 & 58 & 14.4 & 172 & 42.8 & 93 & 23.1 & $\mathbf{3 . 6 2 9 4} *$ & 1.162 \\
\hline 4 & 14 & 3.5 & 56 & 13.9 & 62 & 15.4 & 166 & 41.3 & 104 & 25.9 & $\mathbf{3 . 7 2 1 4} *$ & 1.099 \\
\hline 5 & 38 & 9.5 & 111 & 27.6 & 87 & 21.6 & 108 & 26.9 & 58 & 14.4 & 3.0920 & 1.222 \\
\hline 6 & 33 & 8.2 & 99 & 24.6 & 72 & 17.9 & 130 & 32.3 & 68 & 16.9 & 3.2512 & 1.231 \\
\hline 7 & 34 & 8.5 & 86 & 21.4 & 81 & 20.1 & 143 & 25.6 & 68 & 14.4 & 3.2612 & 1.192 \\
\hline 8 & 29 & 7.2 & 93 & 23.1 & 94 & 23.4 & 127 & 31.6 & 59 & 14.7 & 3.2338 & 1.171 \\
\hline 9 & 76 & 18.9 & 137 & 34.1 & 113 & 28.1 & 46 & 11.4 & 30 & 7.5 & $\mathbf{2 . 5 4 4 8 *}$ & 1.143 \\
\hline 10 & 74 & 18.4 & 124 & 30.8 & 117 & 29.1 & 54 & 13.4 & 33 & 8.2 & $\mathbf{2 . 6 2 1 9 *}$ & 1.170 \\
\hline
\end{tabular}

Source: Created by the authors 
the income level of the family. The data for variables with significant differences are shown below in Table 6. The perception of being treated with prejudice by women in the maritime sector was higher among women participants (272.16) than men (188.61) and this significant difference had a large effect size $(r=-0.52)$. The perception of stereotyped negative thoughts towards women in the maritime sector was higher among women participants (259.97) than men (190.84) and this significant difference had a moderate effect size $(r=-0.23)$. The perception that men were preferred in recruitment in the maritime sector was higher among women (262.47) than men (190.38) and this significant difference had a moderate effect size $(r=-0.24)$. The perception that men advance more easily in the maritime sector was higher among women (236.53) than men (195.11) and this significant difference had a small level of effect size ( $r=-0.13)$. The perception that men were more supported in the maritime sector was higher among women participants (254.94) than men (191.76) and this significant difference had a moderate effect size ( $\mathrm{r}=-0.20)$. The perception that definitions for the stereotyped roles of men and women were used in the maritime sector was higher among women participants (263.02) than men (190.28) and that this significant difference had a moderate effect size $(\mathrm{r}=-0.23)$. The perception of attaching different weights to the thought of women and men in the maritime sector was higher among women participants (258.97) than men (191.02) and this significant difference had a moderate effect size $(r=-0.22)$. The perception of different remuneration between men and women in the maritime sector was higher among women participants (233.23) than men (195.71) and this significant difference had a small effect size $(r=-0.12)$.

The perception that men preferred in recruitment in the maritime sector was higher among Underwater Technology programme students (4.1295) than Marine
Transportation and Management programme students (3.4918) and this significant difference had a medium effect size $\left(\mathrm{e}^{2}: 0.07\right)$. The perception that men advanced more easily in the maritime sector was higher among Underwater Technology programme students(3.5683) than MarineTransportation and Management (2.8402) and Yacht Master (2.8421) programmes students and this significant difference had a medium effect size $\left(\mathrm{e}^{2}: 0.08\right)$. The perception that men were more supported in the maritime sector was higher among Underwater Technology programme students (3.5827) than Marine Transportation and Management programme students (3.0656) and this significant difference had a small effect size $\left(\mathrm{e}^{2}: 0.04\right)$. The perception that definitions for the stereotyped roles of men and women were used in the maritime sector was higher among Yacht Master programme students (3.7368) than Marine Transportation and Management programme students (3.0738) and this significant difference had a small effect size $\left(e^{2}: 0.04\right)$. The perception that different remuneration between men and women in the maritime sector was higher among Yacht Master programme students (3.2105) than Marine Transportation and Management (2.2910) and Underwater Technology (2.8993) programmes students and this significant difference had a medium effect size $\left(\mathrm{e}^{2}: 0.08\right)$. The perception that the existence of different legal arrangements for men and women in the maritime sector was higher among Underwater Technology programme students (3.0504) than Marine Transportation and Management (2.3975) and Yacht Master (2.3684) programme students and this significant difference had a medium effect size $\left(\mathrm{e}^{2}: 0.07\right)$.

The perception that the existence of different remuneration between men and women in the maritime sector was higher among the students who had not an acquaintance in the maritime sector (210.80) than the students who had (161.61) and this 
significant difference had a medium effect size $(\mathrm{r}=-0.17)$. The perception that different legal arrangements for men and women in the maritime sector was higher among the students who had not an acquaintance in the maritime sector (213.71) than the students who had (149.13) and this significant difference had a medium effect size ( $r=-0.22)$.

Table 6. Hypothesis Test Results on Gender Discrimination Based on Profile Information

\begin{tabular}{|c|c|c|c|c|c|c|}
\hline \multirow{3}{*}{$\begin{array}{l}\text { SCALE TO DETECT } \\
\text { PERCEPTION } \\
\text { OF GENDER } \\
\text { DISCRIMINATION } \\
\text { 1- I believe that seafaring } \\
\text { is perceived as a male } \\
\text { profession. }\end{array}$} & \multicolumn{6}{|c|}{ PROFILE VARIABLES } \\
\hline & \multicolumn{2}{|c|}{$\begin{array}{l}\text { Gender } \\
\text { "Mann Whitney U Test" } \\
\text { Differences* }\end{array}$} & \multicolumn{2}{|c|}{$\begin{array}{l}\text { Education programme } \\
\text { "Anova Test" } \\
\text { Differences* }\end{array}$} & \multicolumn{2}{|c|}{$\begin{array}{l}\text { Whether there is a } \\
\text { relative in the sector } \\
\text { "Mann Whitney U Test" } \\
\text { Differences* }\end{array}$} \\
\hline & -- & -- & & -- & -- & -- \\
\hline $\begin{array}{l}2 \text { - I believe women are } \\
\text { being treated biased in } \\
\text { the maritime industry. }\end{array}$ & $\begin{array}{l}\text { U: } 6159.000 \\
\text { p: } \mathbf{0 . 0 0 0} \\
r:-0.52\end{array}$ & $\begin{array}{l}\text { Male : } \\
188.61 \\
\text { Female : } \\
272.16\end{array}$ & & -- & -- & -- \\
\hline $\begin{array}{l}3 \text { - I believe there are } \\
\text { stereotyped negative } \\
\text { thoughts about women } \\
\text { working in the maritime } \\
\text { industry. }\end{array}$ & $\begin{array}{l}\text { U: } 6915.000 \\
\text { p: } \mathbf{0 . 0 0 0} \\
r:-0.23\end{array}$ & $\begin{array}{l}\text { Male : } \\
190.84 \\
\text { Female : } \\
259.97\end{array}$ & & -- & -- & -- \\
\hline $\begin{array}{l}\text { 4- I believe men are more } \\
\text { favoured in recruitment } \\
\text { in the maritime sector. }\end{array}$ & $\begin{array}{l}\text { U: } 6760.000 \\
\text { p: } \mathbf{0 . 0 0 0} \\
r:-0.24\end{array}$ & $\begin{array}{l}\text { Male : } \\
190.38 \\
\text { Female : } \\
262.47\end{array}$ & $\begin{array}{l}F: 16.021 \\
\text { p: } \mathbf{0 . 0 0 0} \\
\mathrm{e}^{2}: 0.07\end{array}$ & $\begin{array}{l}\text { UT }(4.1295)^{*} \\
\text { MTM }(3.4918)^{*}\end{array}$ & -- & -- \\
\hline $\begin{array}{l}5 \text { - I believe men advance } \\
\text { more easily and quickly in } \\
\text { the maritime industry. }\end{array}$ & $\begin{array}{l}\mathrm{U}: 8368.000 \\
\text { p: } \mathbf{0 . 0 0 8} \\
\mathrm{r}:-0.13\end{array}$ & $\begin{array}{l}\text { Male : } \\
\text { 195.11 } \\
\text { Female : } \\
236.53\end{array}$ & $\begin{array}{l}F: 17.440 \\
\text { p: } \mathbf{0 . 0 0 0} \\
e^{2}: 0.08\end{array}$ & $\begin{array}{l}\text { UT }(3.5683)^{*} \\
\text { MTM }(2.8402)^{*} \\
\text { YM }(2.8421)^{*}\end{array}$ & -- & -- \\
\hline $\begin{array}{l}\text { 6- I believe in the } \\
\text { maritime industry } \\
\text { that men are more } \\
\text { supported in professional } \\
\text { development }\end{array}$ & $\begin{array}{l}\text { U: } 7227.000 \\
\text { p: } \mathbf{0 . 0 0 0} \\
\text { r: }-0.20\end{array}$ & $\begin{array}{l}\text { Male : } \\
191.76 \\
\text { Female : } \\
254.94\end{array}$ & $\begin{array}{l}\text { F: } 8.103 \\
\text { p: } 0.000 \\
e^{2}: 0.04\end{array}$ & $\begin{array}{l}\text { UT }(3.5827)^{*} \\
\text { MTM }(3.0656)^{*}\end{array}$ & -- & -- \\
\hline $\begin{array}{l}7 \text { - I believe definitions } \\
\text { are being used for the } \\
\text { stereotypical roles of } \\
\text { men and women in the } \\
\text { maritime industry. }\end{array}$ & $\begin{array}{l}\text { U: } 6726.000 \\
\text { p: } \mathbf{0 . 0 0 0} \\
\text { r: }-0.23\end{array}$ & $\begin{array}{l}\text { Male : } \\
190.28 \\
\text { Female : } \\
263.02\end{array}$ & $\begin{array}{l}\text { F: } 8.226 \\
\text { p: } 0.000 \\
e^{2}: 0.04\end{array}$ & $\begin{array}{l}\text { YM }(3.7368)^{*} \\
\text { MTM }(3.0738)^{*}\end{array}$ & -- & -- \\
\hline $\begin{array}{l}\text { 8- I believe that the words } \\
\text { or opinions of men and } \\
\text { women employees in } \\
\text { the maritime sector are } \\
\text { valued differently. }\end{array}$ & $\begin{array}{l}\text { U: } 6977.000 \\
\text { p: } \mathbf{0 . 0 0 0} \\
\text { r: }-0.22\end{array}$ & $\begin{array}{l}\text { Male : } \\
191.02 \\
\text { Female : } \\
258.97\end{array}$ & & -- & -- & -- \\
\hline
\end{tabular}


Table 6. Hypothesis Test Results on Gender Discrimination Based on Profile Information (Cont')

\begin{tabular}{|c|c|c|c|c|c|c|}
\hline \multirow{2}{*}{$\begin{array}{l}\text { SCALE TO DETECT } \\
\text { PERCEPTION } \\
\text { OF GENDER } \\
\text { DISCRIMINATION }\end{array}$} & \multicolumn{6}{|c|}{ PROFILE VARIABLES } \\
\hline & \multicolumn{2}{|c|}{$\begin{array}{l}\text { Gender } \\
\text { "Mann Whitney U Test" } \\
\text { Differences* }\end{array}$} & \multicolumn{2}{|c|}{$\begin{array}{l}\text { Education programme } \\
\text { "Anova Test" } \\
\text { Differences* }\end{array}$} & \multicolumn{2}{|c|}{$\begin{array}{l}\text { Whether there is a } \\
\text { relative in the sector } \\
\text { "Mann Whitney U Test" } \\
\text { Differences* }\end{array}$} \\
\hline $\begin{array}{l}\text { 9- I believe there is } \\
\text { different remuneration } \\
\text { for men and women } \\
\text { employees in the } \\
\text { maritime sector. }\end{array}$ & $\begin{array}{l}\mathrm{U}: 8572.500 \\
\text { p: } \mathbf{0 . 0 1 5} \\
\mathrm{r}:-0.12\end{array}$ & $\begin{array}{l}\text { Male : } \\
195.71 \\
\text { Female : } \\
233.23\end{array}$ & $\begin{array}{l}\text { F: } 17.218 \\
\text { p: } 0.000 \\
\mathrm{e}^{2}: 0.08\end{array}$ & $\begin{array}{l}\text { YM }(3.2105)^{*} \\
\text { MTM }(2.2910)^{*} \\
\text { UT }(2.8993)^{*}\end{array}$ & $\begin{array}{l}\mathrm{U}: 9356.500 \\
\text { p: } \mathbf{0 . 0 0 1} \\
\text { r: }-0.17\end{array}$ & $\begin{array}{l}\text { Yes : } \\
161.61 \\
\text { No : } \\
210.80\end{array}$ \\
\hline $\begin{array}{l}10 \text { - I believe that different } \\
\text { legal arrangements have } \\
\text { been made for men and } \\
\text { women employees in the } \\
\text { maritime sector }\end{array}$ & -- & -- & $\begin{array}{l}F: 3.822 \\
\text { p: } \mathbf{0 . 0 2 3} \\
\mathrm{e}^{2}: 0.07\end{array}$ & $\begin{array}{l}\text { UT }(3.0504)^{*} \\
\text { YM }(2.3684)^{*} \\
\text { MTM }(2.3975)^{*}\end{array}$ & $\begin{array}{l}\mathrm{U}: 8408.000 \\
\text { p: } \mathbf{0 . 0 0 0} \\
\mathrm{r:}-0.22\end{array}$ & $\begin{array}{l}\text { Yes : } \\
149.13 \\
\text { No : } \\
213.71\end{array}$ \\
\hline
\end{tabular}

Source: Created by the authors

(UT: Underwater Technolgy, MTM: Maritime Transportation and Management, YM:Yacht Master)

\section{Conclusion}

In this study, it was aimed to determine the perceptions of gender discrimination among university students receiving associate degree maritime education and whether the perceptions differ according to demographics. The presence of perceived gender discrimination in the maritime sector, particularly by female students, has been revealed. According to 72nd Article of Turkish Labor Law No. 4857 (10.06.2003) [28] "It is forbidden to employ men under eighteen years of age and women of all ages in underground or underwater works such as mine and cable laying, sewerage and tunnel construction" completely abolishes the employment of women divers. The study is thought to be the result of this regulation, in particular, that Underwater Technology Program students are more involved in the existence of gender discrimination than other programs. Although the regulation article is tried to be intended to protect women against the dangers in underwater, it prevents women to work in the underwater sector other than tourism. On the other hand, there is no obstacle for women to receive education in schools that offer underwater technology education. However, female divers graduated from these schools are unable to find a place in the industrial diving sector due to the limitation of the field of work provided by the regulation.

In Maritime Transport and Management sector, there was not any restriction in law for women employment. But, both Turkish Trade Law and Turkish Maritime Labour Law still do not recognize women seafarers, and women are still enforced to get "Seamen's Book" instead of "Seafarer's Identification Books". This shows that existing legislations are insufficient in recognition of women in all fields of maritime industry [29]. Increasing participation of women in the maritime industry will prevent existing discrimination and inequality in law and practice. Also, the maritime sector, in which women are more involved, will have wellbased working standards, and conditions.

It was concluded that there is prejudice 
against women in the maritime profession, negative thoughts about women, and the perception that men find work easier than women. The fact that there are prejudices and negative thoughts about the existence of women both in the underwater sector and in the maritime transport sector. This situation restricts the ability of women to plan careers in the maritime sector. Therefore, as stated by Nas (2014), the proportion of women in maritime training institutions does not exceed $5 \%$.

The fact that female students' perceptions of gender discrimination were higher than male students' proved that the perspective of women was negative in the sector. Particularly, recording a high level of difference between male and female students in the second question of the scale has indicated that the prejudice against women in the maritime sector has not yet been demolished and that more should be done on the subject. In addition, the perception that the maritime profession is a male profession is not perceived differently by female and male students. This is a promising aspect of the research.

In order to increase the employment rate of women in all branches of the maritime sector, equal approaches should be provided to women both in education, legally, and in work environments. The fact that women are more involved in both a mentally and physically demanding profession, such as maritime, will be an important factor in demolishing stereotyped prejudices in society. It is also thought that the increase in the number of women who contribute to the quality understanding in the sector they enter, will increase dynamism and affect maritime in a positive way.

\section{Discussion and Suggestions}

This study has revealed the existence of gender discrimination in the maritime sector in parallel with the studies conducted by Gutek et al. (1996), Onay (2009), Arl (2013), Davras \& Davras (2014) and Nemlioğlu Koca (2015). In this study gender discrimination has not been analyzed from general perspective. Instead of this approach, the perception of officers candidates and divers candidates were measured separately because of their different dynamics.

To eliminate the prejudice against women in the maritime sector, it is necessary to raise awareness of the sector's dignitaries. Although there have been positive developments, it is thought that there is a further path to be taken both in terms of legislation and in terms of demolishing negative thoughts.

Conducted the study on only the associated degree maritime students is one of the limitation of the study. The other limitation is focusing only to the students on maritime. In future studies, it will be useful to make gender discrimination research on women seafarers and women workers in the maritime sector.

Future studies of the perceptions of gender discrimination in the maritime and aviation sectors, which have similar disciplines, are thought to be useful to ensure that possible differences are looked at from different points of view.

\section{References}

[1] HRDC, (2002). Gender Equality in the Labour Market - Lesson Learned (Final Report), Human Resources Development Canada, Evaluation and Data Development Strategic Policy.

[2] Akın, A. (2007). Toplumsal Cinsiyet (Gender) Ayırımcılığı ve Sağlık. Toplum Hekimliği Bülteni, 26(2), 1-9.

[3 ] Parlaktuna, İ. (2010). Türkiye'de Cinsiyete Dayalı Mesleki Ayrımcılığın Analizi. Ege Akademik Bakış, 10(4), 1217-1230.

[4] United Nations Entity For Gender 
Equality And The Empowerment of Women, Women And Sustainable Development Goals (2019), Retrieved April 15, 2019, from https:// sustainabledevelopment.un.org/ content/documents/ 2322UN\%20 Women $\% 20$ Analysis $\% 20$ on $\% 20$ Women\%20and\%20SDGs.pdf

[5] United Nations Human Development Report (2016), Human Development For Everyone, p.5

[6] World Economic Forum, The Global Gender Gap Report (2017), p.7

[7] United Nations Human Development Report (2018), Human Development For Everyone, p.21

[8] World Economic Forum, The Global Gender Gap Report (2020), p.9

[9] OECD (2018), Short-Term Labour Market Statistics Retrieved May 26, 2019, from https://stats.oecd.org/Index. aspx?DataSetCode=STLABOUR\#

[10] Turkish Statistical Institute, Labor Statistics (2017), Retrieved May 26, 2019.

[11] Safety4sea. (2018). The role of women in shipping continues to grow. Retrieved: April 18, 2019, from https://safety4sea.com/ the-role-of-women-in-shippingcontinues-to-grow/?_cf_chl_jschl_ tk_ =30b7c6749196ae02768 $88 \mathrm{a} 3 \mathrm{aed} 0 \mathrm{e} 578 \mathrm{ab} 27 \mathrm{c}$

f7251593164450-0-

AX4Qo3--

h X C u A v a d t 4 M $25 \mathrm{E} \mathrm{k} \mathrm{m}$ $\begin{array}{lllllllllll}\mathrm{m} & 1 & 8 & 9 & \mathrm{Q} & \mathrm{H} & \mathrm{i} & \mathrm{M} & \mathrm{O} & \mathrm{f} & \mathrm{Y}\end{array}$ Ts3saBy4bLh1lAsGU9 W8Y r Q E 8 g o F 2 r I N 61 c l F s S D z b j 9 GUd4C-A_1_LCXq4Mj16 f3WBzRqdN arfrSbea8b-Iy0 JtxujB1kbIjq-7gPZ Us_aiYZ cbqYrLSir Qk4wVMAq cLqeE-FOPNDzIXBVQziN9KimgFGbc gZu3C3_Hg- Id6i Rzs sPChBJ_6iO_ FpzgkZAUHt3pWfb GG8aOcsT puYf5cJqqDWye _ukzd7iOP w1m1 KwaRtqxQ0fOV pZ4PK sZe0Kw7
XzLOJFGW7VkubWq2zb_ZM LVz6 vuamzTM Pr0aIr YNSmUomQtUcE

[12] Güler, N. (2017). Kadın denizciler. İstanbul Teknik Üniversitesi Tanıtım Bilim, Mühendislik ve Teknolojide Kadın Araştırmaları ve Uygulama Merkezi Dergisi, June, p.6

[13] United nations Food And Agriculture Organization (FAO) (2016), Promoting Gender Equality and Women's Empowerment in Fisheries and Aquaculture, p.1

[14] Popescu, C., \& Varsami, A. E. (2010, July). The place of women in a men's world from a maritime university perspective. In Proceedings of the 7 th WSEAS International Conference on Engineering Education: Latest Trends on Engineering Education, World Scientific and Engineering Academy and Society (WSEAS), (pp.22-24): Corfu Island, Greece,

[15] Şenbursa, N. A Review of Maritime Women in the Global Arena. Deniz Taşımacılığı ve Lojistiği Dergisi, 1(1), 20-25.

[16] Sanchez, J. I., \& Brock, P. (1996). Outcomes of perceived discrimination among Hispanic employees: is diversity management a luxury or a necessity?. Academy of Management Journal, 39(3), 704719.

[17] Gutek, B. A., Cohen, A. G., \& Tsui, A. (1996). Reactions to perceived sex discrimination. Human relations, 49(6), 791-813.

[18] Brickman, J. P. (2008). Maritime education and training of women: their impact on the program at the United States Merchant Marine Academy. In Proceeding of IMLA 16th Conference on MET:'Safety, Security and Quality Objectives on MET Institutions (pp. 283292).

[19] Onay, M. (2009). Algllanan Cinsiyet Ayrımcılığının Sonuçları ve Konuyla 
İlgili Ampirik Bir Araştırma. Ege Akademik Bakış, 9(4), 1101-1125.

[20] Arlı, E. (2013). Deniz Turizm Sektöründe Algllanan Cinsiyet Ayrımcllığı ve Cinsiyet Önyargısı: Karamürsel Meslek Yüksekokulu Öğrencileri Üzerine Bir Araştırma. Calışma ve Toplum : Ekonomi ve Hukuk Dergisi , 38(3), 283-301.

[21] Nas, S. (2014). Profesyonel Türk Kadin Denizcilerinin Kisa Tarihsel Süreci Üzerine Bir Araștırma. Beykoz Akademi Dergisi, 2(1), 29-53.

[22] Cömert, M. (2014). Turizm Eğitimi Alan Öğrencilerin Sektörde Çalıșmak İstedikleri Alanlar Ve Sektördeki İstihdamda Cinsiyet Ayrımcllı̆̆ıla İlgili Düşünceleri. Gazi Üniversitesi Turizm Fakültesi Dergisi, (1), 50-62.

[23] Davras, G. M., \& Davras, Ö. (2015). Thoughts about sex discrimination in tourism sector by student who are in Gastronomy and Culinary Program. Journal of Tourism Theory and Research, 1(2), 86-96.

[24] Nemlioğlu Koca, Y. (2015). Denizcilikte Cinsiyet Ayrımcllı̆̆ ve Önyargı Algısı: Barbaros Denizcilik Yüksekokulu Öğrencileri Üzerine Bir Araştırma. Çalışma ve Toplum : Ekonomi ve Hukuk Dergisi , 44(1), 151-176.

[25] Özcan et al. (2017). A Research About Prediction On Gender Discrimination Related To Engineering. Current Approaches On Business And Economics, 69-88

[26] Tabachnick, B. G. \& Fidell, L. S. (2013). Using Multivariate Statistics, Boston: Pearson.

[27] Cohen, J. (1988). Statistical Power Analysis For the Behavioural Sciences, 2nd Edition, Hillsdale, NJ: L. Erlbaum Associates.

[28] Turkish Labor Law, https:// w w w . m e v z u a t.g o v.t r / MevzuatMetin/1.5.4857.pdf ,p.33
[29] Başak, A. A. (2015). Women's role in the Turkish and global maritime industry. In Maritime Women: Global Leadership (pp. 103-111). 